\title{
Editorial: Signs and communicators
}

\section{Paul Cobley, Adrian Pablé, Johan Siebers}

On 9 and 10 January 2019 the Language and Communication Research Cluster at Middlesex University London hosted the first Middlesex Roundtable on Signs, Language and Communication, with the theme "Integrationism, Biosemiotics, Philosophy of Communication". The roundtable aimed at creating an opportunity for dialogue among representatives of these approaches to the study of communication. The workshop was the result of the joint effort of the research cluster, the International Society for Biosemiotic Studies, the International Association for the Integrational Study of Language and Communication (IAISLC) and the Section for Philosophy of Communication of the European Communication Research and Education Association (ECREA).

We are grateful for having the opportunity, offered to us by one of the participants in the Roundtable, Kalevi Kull, to prepare this issue of Sign Systems Studies on the basis of a selection of the papers presented at the workshop.

While there are vast differences in aims and orientation of the three fields that the workshop brought together, there are also similarities. Integrationism, the language and communication theory of Roy Harris, seeks to dispel what it calls the 'language myth': the idea that language is an entirely separate mode of communication, that languages are systems of abstract linguistic signs, that linguistic communication involves the transmission or reproduction of mental content between individuals. Harris uses the dismissive term 'telementation' for the latter view, an implicit assumption in our lay thinking about how linguistic communication works. Instead, integrationism holds, the sign is a ubiquitous feature of all experience, is radically contextualized and individual, and is that by which a subject "integrates" what it encounters in the constitution of its being. Signs come into being the moment they are needed and they perish as soon as an individual act of integration has been completed. Not only language is a practice of integration; any relationality that we can think of comes about on the basis of integrating cotemporal activities of various kinds. Integrationism takes the radical nature of its proposal seriously: as sign-making is a radically contextual and 
individual affair, there is no objective outsider-perspective, no view from nowhere that could claim priority with respect to the nature of first-order sign-making practices as they occur in real life. We are always our own best communication theorists, as we know what we are doing when we communicate. We are after all the ones who are doing it. This implies that we can say nothing about non-human communicators and the world that they live in. Integrationism is a humanism by default. Linguistics as a science has no place in integrationist thought; rather, integrationism invites us to think of linguistics, first of all in terms of a wider, more generalized communication theory of semiological integration and secondly, as a reflection on communication that is part and parcel of our existence as communicative agents. Linguistics is the whole field of communication about communication, radically anarchistic and democratic, if you will, in which everyone has equal rights to a seat at the table when it comes to articulating what communication is. The theory of communication itself (an activity that does have some insights to convey, after all) is just one aspect of the reflexive nature of language use that accompanies us as we live our sign-making lives; it can claim no priority of pre-eminence; if someone happens to find themselves puzzled by certain questions about what happens when we communicate, they may find help there, but that is all.

The field of biosemiotics shares with integrationism the aim of relaxing the ontological divide between language and the world, although it does so with a slightly different purview. In the landmark volume which first tested the 'integration' of semiotics and integrationism, providing the impetus for the Roundtable, Adrian Pablé and Christopher Hutton (2015: 18) wrote, "The relationship between the individual self, the species and the environment is of central concern to semiotic theory. Whereas integrationism takes a largely anthropocentric view of the self, post-Peircean semiotics views human beings within a much wider biosemiotic frame". For most biosemioticians the making and using of signs is not limited to human conscious, mediated communication. Inspired by the discovery of the genetic code at work in the heart of the reproduction of life, biosemiotics has, over the years, developed a paradigm for the study of signs that universalizes semiosis to life as such, and for some even into the inorganic realm, looking at the function of information in the constitution, preservation and transformation of matter and in causal relations. Typically, for biosemiotics, sign-making and sign-using or sign-interpreting does, in some areas, fall back on a code; but the ontological status of the code is not fixed universally and in advance. As biosemiotics has developed, it has sought to shake off its philosophical swaddling clothes and understand itself as a scientific theory about life, capable of experimental verification, refining and further development. Biosemiotics is 
not, to use a Harrisian term, lay-oriented, in that it does not see the process of semiosis as radically inaccessible to anyone other than the agents engaged in it. Much of the dialogue between biosemiotics and integrationism hinges on the question as to the status of the "language myth": is the mythical reification of code, eschewed by biosemiotics but present in earlier incarnations of sign theory, perhaps an inevitable dimension of semiosis, one that we can subsequently free ourselves from, if we are so propelled, but nevertheless an operative fiction in the organization and evolution of ever more complex forms of interaction?

Whereas these two paradigms can rightly claim their status as full-fledged theoretical proposals about the nature of communication and semiosis, the philosophy of communication is rather more a disciplinary sub-field than a single paradigm. The term 'philosophy of communication' has been around for some time, although as yet there are only a few people who identify their thinking as such. Most of these are gathered together in ECREA's Philosophy of Communication Section, an association of scholars set up by Johan Siebers and Tino Meitz shortly after the foundation of ECREA with the explicit aim to stimulate work at the interface of communication studies and philosophy. While communication has been a well-established topic of interest to philosophers from pre-Socratic times onwards, there has been relatively little attention to the way in which an orientation toward communication can provide new ways of thinking about philosophical questions. From the beginning, the Section sought to create opportunities for philosophical thought about communication, but also for communicative thought about philosophy. As a consequence, philosophy of communication distinguishes itself from communication theory, the plethora of conceptualizations of communication that inform the field of communication studies. Philosophy is perhaps part of theory, but if so in a distinctive way, concerned with distinctive questions, perspectives, approaches and methods (to the extent to which philosophy can be said to have a method or be methodical at all). None of the boundaries are non-porous here, but philosophers of communication have been adamant about philosophy as a sui generis activity within the broader, inclusive notion of theory. Where will the philosophy of communication go? It seems that the world today has more need than ever to develop new, more penetrating ways of thinking about communication and its place in our lives. Many institutions, cultural practices and values are undergoing profound and still often poorly understood transformations in the wake of the communication revolutions of the past decades, with wide-ranging ethical, epistemological and political effects. It could well be that we have to allow our understanding of communication to fertilize what we mean by ethics, epistemology and political thinking (and, as one contribution in this issue argues, also what we mean by 
ontology and metaphysics) before philosophy can usefully address the most fundamental dimensions of these changes and provide new orientations for praxis. The dialogue between philosophy, integrationism and biosemiotics is one example of exploring that fertilization.

This issue starts with a contribution by Charlotte Conrad, who investigates the idea of reality as a construct based on pragmatic semiosis, conceptualized along integrationist lines. The notion of reality as interface emerges as result. Peter Kastberg writes about reciprocal dynamics of dialogue and uses constructivist approaches to develop a communication-philosophical physiognomy of dialogic interaction.

Next, two empirical studies explore the relevance of some of the conceptualizations of our paradigms in understanding mediated communication. Cary Bazalgette discusses her work on the early stages of learning to read film and TV, while Dorthe Duncker considers the case of chatbots through the lens of Harrisian sign-making, and addresses questions of subjectivity and personhood in humancomputer dialogic interaction.

The third section of this issue deals with more strictly theoretical and critical questions. Chris Farnham explores the relevance of Peirce's notion of the object as a way of making Hegelian dialectical thinking fruitful for understanding semiosis. Adrian Pablé investigates if - and if so, how - aspects of biosemiotics might be integrated into integrationism; the question of the default humanism of the integrationist understanding of sign-making is opened up and examined here. Johan Siebers' contribution looks at the ontology of communication and sketches the outlines of a programme for such an ontology, in which communication is theorized in terms of being and being in terms of communication. Finally, Paul Cobley's contribution speaks to the theme of the radical subjectivity of sign-making in integrationism by discussing the work of leading integrationist Christopher Hutton and providing a critical biosemiotic perspective on personhood.

We wish the reader a pleasurable and hopefully enriching time, joining the authors on their explorations along new and untrodden pathways into the vast and fascinating landscape of communication, and developing their own thoughts on some of these questions as they go. For whether we subscribe, in the end, to the radical humanism of integrationism or not, the semiotically self-conscious words of Schopenhauer ring true: "Thoughts reduced to paper are generally nothing more than the footprints of a man walking in the sand. It is true that we see the path he has taken; but to know what he saw on the way, we must use our own eyes" (Schopenhauer 1974: \$291). 


\section{References}

Pablé, Adrian; Hutton, Christopher 2015. Signs, Meaning and Experience. Berlin: De Gruyter. Schopenhauer, Arthur 1974. Parerga and Paralipomena: Short Philosophical Essays. Vol. 2. (Payne, Eric F. J., trans.) Oxford: Oxford University Press. 